\title{
FAKTOR YANG MEMPENGARUHI PENGGUNAAN JENIS METODE KONTRASEPSI JANGKA PANJANG (MKJP) PADA WANITA MENIKAH USIA SUBUR DI PROVINSI JAWA TIMUR
}

\author{
Luki Triyanto $^{1}$, Diah Indriani ${ }^{2}$ \\ ${ }^{1,2}$ Departemen Biostatistika dan Kependudukan \\ Fakultas Kesehatan Masyarakat, Universitas Airlangga \\ Alamat Korespondensi: Luki Triyanto \\ Email: luki.triyanto@gmail.com
}

\begin{abstract}
Long-Acting and Permanent Method (LAPM) is a very effective method of contraception, but women of childbearing age majority use short-term contraceptive methods. The purpose of this study was to apply multinomial logistic regression analysis in predicting factors affecting Fertile Women in the use of LAPM in East Java Province in 2012. This research use secondary data that was result of Indonesia Demographic Health Surveys (IDHS) year 2012 using the number of 171 respondents. The results of this study indicated the variables that affected the use of LAPM of WUS age $(p=0.008)$, education level $(p=0,004)$, occupation $(p=0,029)$, source of family planning services $(p=0,000)$, residence area $(p=0.016)$. The conclusion of this study was age, educational level, occupation, source of FP services, and residential areas affecting the use of long-term contraceptive methods in women of childbearing age. Therefore the government through the National Family Planning Coordinating Board (BKKBN), still pay attention to the family planning program and ensure every community to implement family planning programs and educate and promote family planning programs to resolve the problems of the population.
\end{abstract}

Keywords: multinomial logistic regression, LAPM, women of childbearing age.

\begin{abstract}
ABSTRAK
Metode Kontrasepsi Jangka Panjang (MKJP) adalah metode kontrasepsi yang sangat efektif, tetapi wanita mayoritas usia subur menggunakan metode kontrasepsi jangka pendek. Tujuan penelitian ini adalah untuk menerapkan analisis regresi logistik multinomial dalam memprediksi faktor-faktor yang mempengaruhi Wanita Usia Subur dalam penggunaan MKJP di Provinsi Jawa Timur pada tahun 2012. Penelitian ini menggunakan data sekunder yang merupakan hasil SDKI tahun 2012 dengan jumlah 171 responden. Hasil penelitian ini menunjukkan variabel yang mempengaruhi penggunaan MKJP usia WUS $(p=0,008)$, tingkat pendidikan $(p=$ $0,004)$, pekerjaan $(p=0,029)$, sumber layanan keluarga berencana $(p=0,000)$, daerah tempat tinggal $(p=$ 0,016). Kesimpulan dari penelitian ini adalah usia, tingkat pendidikan, pekerjaan, sumber layanan KB, dan daerah pemukiman mempengaruhi penggunaan MKJP pada WUS. Karena itu pemerintah melalui Badan Kependudukan dan Keluarga Berencana Nasional (BKKBN) tetap memperhatikan program keluarga berencana dan memastikan setiap masyarakat untuk menerapkan program keluarga berencana, serta mendidik dan mempromosikan program keluarga berencana untuk menyelesaikan permasalahan penduduk.
\end{abstract}

Kata kunci: regresi logistik multinomial, MKJP, wanita usia subur.

\section{PENDAHULUAN}

Analisis regresi logistik merupakan salah satu pendekatan model matematis yang digunakan untuk menganalisis hubungan antara variabel dependen yaitu kategori yang bersifat dikotom atau polikotomus dengan variabel independen berupa skala pengukuran nominal, ordinal, interval, maupun rasio (Kuntoro, 2007).
Regresi logistik multinomial adalah sebuah analisis regresi logistik yang menggunakan variabel dependen yang bersifat polikotomus atau multinomial (lebih dari dua kategori berskala nominal) (Hosmer dan Lemeshow, 2000). Analisis regresi logistik multinomial digunakan untuk pemodelan faktor risiko yang bertujuan untuk memprediksi pengaruh antara suatu determinan dengan masalah kesehatan 
sehingga dapat memprediksi faktor yang mempengaruhi penggunaan Metode Kontrasepsi Jangka Panjang (MKJP). MKJP merupakan usaha pemerintah dalam menekan pertambahan penduduk. Permasalahan pertumbuhan penduduk yang mengalami peningkatan, membutuhkan adanya suatu usaha dari masyarakat dan pemerintah. Dalam rangka menekan laju pertumbuhan penduduk pemerintah melaksanakan berbagai program pembangunan, salah satunya Keluarga Berencana (KB) bagi Pasangan Usia Subur (PUS) (BPS, 2013). Keluarga Berencana merupakan usaha untuk menjarangkan atau merencanakan jumlah anak dan jarak kehamilan dengan cara memakai kontrasepsi dan menciptakan kesejahteraan ekonomi dan sosial bagi seluruh masyarakat melalui usaha perencanaan dan pengendalian penduduk (Saifuddin, 2006).

Berdasarkan hasil Survei

Demografi Kesehatan Indonesia (SDKI) tahun 2012 peserta KB aktif Contraceptive Prevalence Rate (CPR) pasangan usia subur mencapai 61,9\% (BPS, 2013). Pada hasil Survei Penduduk Antar Sensus (SUPAS) tahun 2015 terdapat penurunan dibandingkan hasil SDKI 2012. Angka prevalensi pemakaian kontrasepsi semua metode hasil SUPAS 2015 sebesar 57,9\% dan kontrasepsi modern 57,1\%. Dari sekian banyak pengguna aktif dan banyak metode kontrasepsi yang ditawarkan, metode suntikan KB merupakan metode yang banyak digunakan (BKKBN, 2015).

Berdasarkan hasil SDKI 2012 prevalensi $\mathrm{KB}$ aktif di Indonesia 58\% wanita berstatus kawin umur 15-49 tahun menggunakan metode modern dan 4\% menggunakan metode tradisional. Suntikan $\mathrm{KB}$ adalah metode kontrasepsi yang paling banyak digunakan, diikuti oleh pil, masingmasing sebesar $32 \%$ dan $14 \%$. Kemudian Intra Uterine Device (IUD) sebesar 4\%, susuk KB/implan sebesar 3,3\%, secara medis yaitu Medis Operatif Wanita (MOW) sebesar 3,2\%, sedangkan untuk pria yaitu Medis Operatif Pria (MOP) dan penggunaan kondom masih sangat rendah yaitu sebesar 3\% (SDKI, 2013). Suntikan $\mathrm{KB}$ dan pil merupakan metode $\mathrm{KB}$ hormonal yang termasuk metode kontrasepsi jangka pendek, yang rentan terhadap kegagalan dan tingkat drop out yang cukup tinggi mencapai 23-39\%, sementara metode kontrasepsi jangka panjang hanya sekitar $0,5-10 \%$ (Bapennas, 2012).

Berdasarkan hasil sensus penduduk tahun 2010, jumlah penduduk di Jawa Timur menjadi salah satu yang terbanyak, yaitu sebesar 37,476 juta orang dan mengalami peningkatan hingga tahun 2016 sebesar 39,075 juta orang (BPS, 2017). Cakupan jumlah PUS di Jawa Timur yang menjadi akseptor KB dalam 3 (tiga) tahun terakhir berfluktuasi sebesar $72,77 \%$ pada tahun $2014,84,44 \%$ pada tahun 2015 , dan mengalami penurunan menjadi $68,79 \%$ pada tahun 2016 (Dinkes, 2017). Berdasarkan hasil evaluasi BKKBN Jawa Timur sampai dengan bulan Februari tahun 2017 cakupan peserta KB aktif berdasarkan kontrasepsi yang digunakan sebesar 74,39\%. Alat kontrasepsi yang paling banyak diminati oleh peserta KB aktif adalah jenis non MKJP yang terdiri dari suntik, pil, dan kondom, sedangkan untuk MKJP masih cukup rendah yang terdiri dari IUD, MOP, MOW dan implan.

Penelitian yang dilakukan Magetin (2016), menunjukkan bahwa umur istri, jumlah anak dan tingkat pendidikan memiliki hubungan yang signifikan dengan pemilihan jenis kontrasepsi yang digunakan. Umur berpengaruh dengan struktur organ, fungsi organ, komposisi biokimiawi dan sistem hormonal, sehingga pada periode umur tertentu dapat menyebabkan perbedaan pada kontrasepsi yang dibutuhkan. Jumlah anak yang masih hidup juga berkaitan dengan perencanaan keluarga dari pasangan suami istri dan tingkat kesejahteraan keluarga. Pasangan yang memiliki anak masih sedikit memiliki peluang atau kecenderungan untuk menggunakan kontrasepsi dengan efektifitas rendah, sedangkan pasangan 
dengan jumlah anak hidup banyak cenderung untuk menggunakan kontrasepsi dengan efektifitas tinggi. Tingkat pendidikan juga mempunyai pengaruh dalam menentukan pilihan, karena seseorang yang memiliki pendidikan tinggi pada umumnya akan lebih luas pandangannya dan lebih mudah menerima ide maupun hal-hal inovatif.

Faktor lain yang mempengaruhi pemilihan metode kontrasepsi adalah fasilitas kesehatan (Stephenson dkk, 2008). Fasilitas kesehatan sangat penting dalam keberhasilan program KB. Fasilitas kesehatan sebagai penyedia alat/cara kontrasepsi, selain itu harus melakukan upaya dalam peningkatan akseptor KB dan melakukan pelayanan promotif dan preventif sehingga pasangan usia subur dapat secara rasional dalam penggunaan kontrasepsi yang sesuai kebutuhan.

Sedangkan untuk menggunakan MKJP, faktor yang ditemukan signifikan diantaranya usia, jumlah anak hidup, tingkat pendidikan, lama pernikahan, sumber pelayanan $\mathrm{KB}$ dan tujuan ber $\mathrm{KB}$ (Nasution, 2011).

Berdasarkan penelitian Magetin dan faktor kondisi yang ada di Provinsi Jawa Timur, maka dilakukan penelitian terkait faktor yang mempengaruhi penggunaan jenis MKJP dengan analisis uji regresi logistik multinomial karena pada penelitian ini dependen variabelnya nominal lebih dari 2 (dua) kategori.

\section{METODE PENELITIAN}

Penelitian ini termasuk jenis penelitian non reaktif atau unobstrusive yaitu penelitian yang tidak memerlukan respon dari subyek yang diteliti dan tidak ada interaksi antara peneliti dan subyek penelitian. Data yang digunakan adalah data sekunder SDKI 2012. Lokasi penelitian berada di Provinsi Jawa Timur. Penelitian ini mengambil data SDKI tahun 2012 yang berada di wilayah Provinsi Jawa Timur. Populasi dari SDKI 2012 adalah Wanita Usia Subur (WUS).
Teknik sampling pada penelitian ini adalah multi stage sampling. Besar sampel keseluruhan berdasarkan SDKI sebanyak 45.607 responden. Sesuai dengan kriteria dengan keinginan peneliti, maka pada penelitian ini diperoleh sampel sebesar 171 responden. Variabel independen pada penelitian ini umur, tingkat pendidikan, daerah tempat tinggal. Variabel dependen metode kontrasepsi jangka panjang pada wanita (IUD, MOW, dan implan).

Data yang diperoleh, selanjutnya diolah dan dianalisis secara komputerisasi. Analisis Data dalam penelitian ini bertujuan untuk memprediksi faktor yang mempengaruhi penggunaan metode kontrasepsi jangka panjang. Analisis data yang dilakukan berupa analisis deskriptif dan analisis regresi logistik. Analisis deskriptif yang digunakan adalah distribusi frekuensi dan tabel statistik deskriptif yang digunakan untuk mendeskripsikan variabel penelitian guna memperoleh gambaran karakteristik penelitian. Metode yang digunakan untuk menganalisis data adalah regresi logistik multinomial dengan bantuan software statistik.

\section{HASIL}

\section{Gambaran Distribusi Frekuensi pengguna MKJP Pada WUS di Provinsi Jawa Timur tahun 2012}

Tabel 1. Distribusi Pengguna MKJP di Provinsi Jawa Timur tahun 2012

\begin{tabular}{lcc}
\multicolumn{1}{c}{ MKJP } & Frekuensi & \% \\
\hline IUD & 73 & 42,7 \\
\hline MOW & 52 & 30,4 \\
\hline Implan & 46 & 26,9 \\
\hline \multicolumn{1}{c}{ Total } & 171 & 100 \\
\hline
\end{tabular}

Jumlah WUS di Jawa Timur berdasarkan data SDKI tahun 2012 berjumlah 1635 orang. Jumlah WUS yang telah menikah dan menggunakan kontrasepsi sebanyak 1014 orang, sebanyak 171 responden. Berikut 
merupakan tabel penggunaan metode kontrasepsi jangka panjang (IUD, MOW dan Implan) di Jawa Timur.

Tabel 1 menunjukkan persentase WUS yang menggunakan MKJP dengan metode IUD sebanyak 42,7\%, metode MOW sebesar 30,4\%, dan metode implan sebesar $26,9 \%$.

Tabel 2. Distribusi Pengguna MKJP Pada WUS Berdasarkan Umur di Provinsi Jawa Timur tahun 2012

\begin{tabular}{ccccc}
\hline \multirow{2}{*}{ Umur } & \multicolumn{3}{c}{ MKJP } & Total \\
\cline { 2 - 4 } & IUD & MOW & Implan & \\
\hline \multirow{2}{*}{$\leq 30$} & 13 & 0 & 17 & 30 \\
& $(43,3)$ & $(0)$ & $(56,7)$ & $(100)$ \\
\hline \multirow{2}{*}{$>30$} & 60 & 52 & 29 & 141 \\
& $(42,6)$ & $(36,9)$ & $(20,6)$ & $(100)$ \\
\hline Total & 73 & 52 & 46 & 171 \\
& $(42,7)$ & $(30,4)$ & $(26,9)$ & $(100)$
\end{tabular}

Keterangan:

Angka (dalam kurung) dinyatakan dalam satuan persen $(\%)$

Tabel 2 menunjukkan bahwa WUS dengan umur (kurang dari 30) tahun yang menggunakan MKJP sebanyak 30 orang dan WUS yang menggunakan metode MKJP yang banyak dipilih adalah metode implan sebesar 56,7\%.

Tabel 3. Distribusi Pengguna MKJP pada WUS Berdasarkan Tingkat Pendidikan di Provinsi Jawa Timur tahun 2012

\begin{tabular}{lcccc}
\hline Pend. & \multicolumn{3}{c}{ MKJP } & Total \\
\cline { 2 - 4 } & IUD & MOW & Implan & \\
\hline \multirow{2}{*}{ TS } & 1 & 1 & 4 & 6 \\
& $(16,7)$ & $(16,7)$ & $(66,7)$ & $(100)$ \\
\hline \multirow{2}{*}{ SD } & 29 & 23 & 19 & 71 \\
& $(40,8)$ & $(32,4)$ & $(26,8)$ & $(100)$ \\
\hline SMP & 29 & 25 & 20 & 74 \\
& $(39,2)$ & $(33,8)$ & $(27)$ & $(100)$ \\
\hline SMA & 14 & 3 & 3 & 20 \\
& $(70)$ & $(15)$ & $(15)$ & $(100)$ \\
\hline Total & 73 & 52 & 46 & 171 \\
& $(42,7)$ & $(30,4)$ & $(26,9)$ & $(100)$ \\
\hline Keterangan: & & & \\
TS & $:$ Tidak Sekolah & &
\end{tabular}

TS : Tidak Sekolah
Tabel 3 menunjukkan bahwa pendidikan yang dimiliki wanita usia subur beragam dari yang tidak sekolah hingga dengan pendidikan Sekolah Menengah Atas. Wanita usia subur dengan tingkat pendidikan Sekolah Menengah Atas sebanyak $70 \%$ memilih menggunakan Intrauterine Device (IUD).

Tabel 4. Distribusi Pengguna MKJP Pada WUS Berdasarkan Daerah Tempat Tinggal di Provinsi Jawa Timur tahun 2012

\begin{tabular}{ccccc}
\hline \multirow{2}{*}{ TT } & \multicolumn{3}{c}{ MKJP } & Total \\
\cline { 2 - 4 } & IUD & MOW & Implan & \\
\hline \multirow{2}{*}{ Kota } & 37 & 30 & 24 & 91 \\
& $(40,7)$ & $(33)$ & $(26,4)$ & $(100)$ \\
\hline \multirow{2}{*}{ Desa } & 36 & 22 & 22 & 80 \\
& $(45)$ & $(27,5)$ & $(27,5)$ & $(100)$ \\
Total & 73 & 52 & 46 & 171 \\
& $(42,7)$ & $(30,4)$ & $(26,9)$ & $(100)$ \\
& & & & \\
\hline
\end{tabular}

Keterangan:

TT : Tempat Tinggal

Tabel 4 menunjukkan bahwa wanita usia subur di Provinsi Jawa Timur memiliki penyebaran yang cukup merata di daerah perkotaan maupun daerah pedesaan. Penggunaan metode Intrauterine Device (IUD) paling banyak digunakan oleh wanita usia subur yang berada di daerah pedesaan sebanyak $45 \%$.

Tabel 5. Distribusi Pengguna MKJP Pada WUS berdasarkan pekerjaan di Provinsi Jawa Timur tahun 2012

\begin{tabular}{ccccc}
\hline $\begin{array}{c}\text { Pekerja } \\
\text { an }\end{array}$ & \multicolumn{3}{c}{ MKJP } & Total \\
\cline { 2 - 4 } & IUD & MOW & Implan & \\
\hline Tdk & 22 & 16 & 24 & 62 \\
Kerja & $(35,5)$ & $(25,8)$ & $(26,4)$ & $(100)$ \\
\hline Kerja & 51 & 36 & 22 & 109 \\
& $(46,8)$ & $(33)$ & $(20,2)$ & $(100)$ \\
\hline Total & 73 & 52 & 46 & 171 \\
& $(42,7)$ & $(30,4)$ & $(26,9)$ & $(100)$ \\
& & & & \\
\hline
\end{tabular}

Tabel 5 menunjukkan bahwa WUS di Provinsi Jawa Timur ada yang bekerja 
dan tidak bekerja. WUS yang memiliki pekerjaan memilih menggunakan IUD sebesar $46,8 \%$.

Tabel 6. Distribusi Sumber Pelayanan Pengguna MKJP Pada WUS di Provinsi Jawa Timur tahun 2012

\begin{tabular}{lcccc}
\hline $\begin{array}{c}\text { Pelayan } \\
\text { an }\end{array}$ & \multicolumn{3}{c}{ MKJP } & \multirow{2}{*}{ Total } \\
\cline { 2 - 4 } RSP & IUD & MOW & Implan & \\
\hline \multirow{2}{*}{ PKM } & $(22)$ & $(78)$ & $(0)$ & $(100)$ \\
\hline RS & 29 & 9 & 22 & 60 \\
Swasta & $(48,3)$ & $(24,2)$ & $(27,5)$ & $(100)$ \\
\hline \multirow{2}{*}{ Bidan } & 2 & 9 & 0 & 11 \\
& $(71)$ & $(0)$ & $(29)$ & $(100)$ \\
\hline \multirow{2}{*}{ Lainnya } & 11 & 11 & 6 & 28 \\
& $(39,3)$ & $(39,3)$ & $(21,4)$ & $(100)$ \\
\hline Total & 73 & 61 & 37 & 171 \\
& $(42,7)$ & $(30,4)$ & $(26,9)$ & $(100)$ \\
\hline Ket & & & & \\
\hline
\end{tabular}

Keterangan:

RSP : Rumah Sakit Pemerintah

PKM : Puskesmas

Tabel 6 menunjukkan pemasangan kontrasepsi oleh WUS dengan metode MOW dilakukan di RS Swasta sebesar $81,8 \%$ dan di RS Pemerintah sebesar 78\%.

Sedangkan penggunaan kontrasepsi dengan metode IUD dengan memanfaatkan tenaga bidan sebesar $71 \%$ dan di Puskesmas dipilih oleh WUS dalam penggunaan dan pemasangan IUD sebesar $48,3 \%$.

\section{Regresi Logistik Multinomial dari Faktor yang Mempengaruhi Penggunaan MKJP pada WUS di Provinsi Jawa Timur Tahun 2012}

Tabel 7. Indikator Model Fit

\begin{tabular}{lllll}
\hline & $\begin{array}{l}\text { Model } \\
\text { Fitting } \\
\text { Criteria }\end{array}$ & \multicolumn{2}{c}{ Likelihood Ratio Tests } \\
& $\begin{array}{l}\text {-2 Log } \\
\text { Likelihoo } \\
\text { d }\end{array}$ & $\begin{array}{l}\text { Chi- } \\
\text { Square }\end{array}$ & Df & Sig. \\
\hline $\begin{array}{l}\text { Model } \\
\text { Final }\end{array}$ & 96,934 & 182,337 & 20 & 0,000 \\
\hline
\end{tabular}

Tabel 7 menunjukkan bahwa nilai Sig. ( $p$-value) kurang dari 0,05, sehingga model tersebut memiliki signifikansi dan dapat diaplikasikan dalam memprediski faktor yang mempengaruhi penggunaan metode kontrasepsi jangka panjang pada wanita menikah usia subur.

Tabel 8. Likelihood Ratio Tests

\begin{tabular}{lcccc}
\hline \multirow{2}{*}{ Effect } & $\begin{array}{l}\text { Model } \\
\text { Fitting } \\
\text { Criteria }\end{array}$ & \multicolumn{2}{l}{ Likelihood Ratio Tests } \\
\cline { 2 - 5 } & $\begin{array}{l}\text {-2 Log } \\
\text { Likelihood }\end{array}$ & $\begin{array}{l}\text { Chi- } \\
\text { Square }\end{array}$ & Df & Sig. \\
\hline Kons. & $96,934^{\text {a }}$ & .000 & 0 & \\
\hline Umur & 119,463 & 22,529 & 2 & .000 \\
\hline Pend. & 113,449 & 16,515 & 6 & .011 \\
\hline TT & 104,467 & 7,542 & 2 & .023 \\
\hline $\begin{array}{l}\text { Pekerja } \\
\text { an }\end{array}$ & 103,360 & 6,426 & 2 & .040 \\
\hline $\begin{array}{l}\text { Sumber } \\
\text { Pelayan } \\
\text { an }\end{array}$ & 225,299 & 128,365 & 8 & .000 \\
\hline Kenyyyyy & & & & \\
\hline
\end{tabular}

Keterangan:

Kons. : Konstanta

Tabel 8 menunjukkan adanya variabel yang memberikan kontribusi pada model adalah variabel dengan nilai Sig. ( $p$ value) kurang dari 0,05 . Variabel tersebut antara lain umur, pendidikan, daerat tempat tinggal, pekerjaan dan sumber pelayanan.

Tabel 9. Uji Kesesuaian Model Regresi Logistik Multinomial

\begin{tabular}{llcc}
\hline & $\begin{array}{l}\text { Chi- } \\
\text { Square }\end{array}$ & Df & Sig. \\
\hline Pearson & 44,397 & 110 & 1,000 \\
\hline Deviance & 53,896 & 110 & 1,000 \\
\hline
\end{tabular}

Tabel 9 menunjukkan nilai Sig. ( $p$ value) yaitu sebesar 1,000 lebih dari 0,05, sehingga dapat diartikan bahwa model dapat diterima dan model dapat dibentuk, karena tidak terdapat perbedaan yang signifikan antara model dengan nilai observasinya. 
Tabel 10. Uji Multivariat Faktor yang Berpengaruh terhadap Penggunaan MKJP di Provinsi Jawa Timur tahun 2012

\begin{tabular}{|c|c|c|c|c|}
\hline \multicolumn{2}{|c|}{ Faktor } & Koefisien & $\begin{array}{c}P \text { - } \\
\text { value }\end{array}$ & $\begin{array}{c}\operatorname{Exp} \\
\text { (B) }\end{array}$ \\
\hline \multirow{22}{*}{$\begin{array}{l}\text { IUD } \\
\text { (I) }\end{array}$} & Kons. & 3,619 & 0,002 & \\
\hline & Umur & & & \\
\hline & $\leq 30$ & $-1,528$ & 0,008 & .218 \\
\hline & $>30$ & \multicolumn{3}{|c|}{$\begin{array}{c}\text { Pembanding (Reference } \\
\text { Group) }\end{array}$} \\
\hline & \multicolumn{4}{|c|}{ Tingkat Pendidikan } \\
\hline & TS & $-4,214$ & 0,004 & 0,015 \\
\hline & SD & $-1,700$ & 0,059 & 0,183 \\
\hline & SMP & $-1,128$ & 0,182 & 0,324 \\
\hline & SMA & \multicolumn{3}{|c|}{$\begin{array}{c}\text { Pembanding (Reference } \\
\text { Group) }\end{array}$} \\
\hline & \multicolumn{4}{|c|}{ Pekerjaan } \\
\hline & Tidak & $-1,072$ & 0,030 & 0,342 \\
\hline & $\mathrm{Ya}$ & \multicolumn{3}{|c|}{$\begin{array}{c}\text { Pembanding (Reference } \\
\text { Group) }\end{array}$} \\
\hline & \multicolumn{4}{|c|}{ Daerah Tempat Tinggal } \\
\hline & Desa & $-0,725$ & 0,104 & .484 \\
\hline & Kota & \multicolumn{3}{|c|}{$\begin{array}{c}\text { Pembanding (Reference } \\
\text { Group) }\end{array}$} \\
\hline & \multicolumn{4}{|c|}{ Sumber Pelayanan } \\
\hline & RSP & 18,685 & 0,000 & $\begin{array}{c}1,303 \\
\mathrm{E} 8\end{array}$ \\
\hline & PKM & $-0,939$ & 0,149 & 0,391 \\
\hline & RS & 18,319 & 0,000 & 9,033 \\
\hline & Swasta & & & E7 \\
\hline & Bidan & $-0,62$ & 0,936 & 0,940 \\
\hline & Lainnya & \multicolumn{3}{|c|}{$\begin{array}{c}\text { Pembanding (Reference } \\
\text { Group) }\end{array}$} \\
\hline \multirow{7}{*}{$\begin{array}{l}\text { MOW } \\
\text { (II) }\end{array}$} & Kons. & 2,707 & 0,77 & \\
\hline & Pekerjaa & & & \\
\hline & Tidak & $-1,072$ & 0,030 & 0,342 \\
\hline & $\mathrm{Ya}$ & \multicolumn{3}{|c|}{$\begin{array}{c}\text { Pembanding (Reference } \\
\text { Group) }\end{array}$} \\
\hline & \multicolumn{4}{|c|}{ Daerah Tempat Tinggal } \\
\hline & Desa & $-2,103$ & 0,016 & 0,122 \\
\hline & Kota & \multicolumn{3}{|c|}{$\begin{array}{c}\text { Pembanding (Reference } \\
\text { Group) }\end{array}$} \\
\hline
\end{tabular}

Kelompok pembanding: Implan
Pada Tabel 10 menunjukkan hasil analisis regresi logistik multinomial terdapat variabel yang signifikan berpengaruh terhadap pemilihan MKJP pada WUS dengan nilai ( $p$-value) kurang dari 0,05 .

Model pertama membandingkan antara wanita usia subur yang menggunakan metode kontrasepsi jangka panjang jenis IUD dengan wanita usia subur yang menggunakan metode kontrasepsi jangka panjang jenis Implan. Wanita usia subur yang berumur lebih dari 30 tahun kemungkinan untuk menggunakan MKJP IUD sebesar 4,587 kali dibandingkan dengan WUS yang berumur kurang dari sama dengan 30 tahun; WUS yang memiliki pendidikan SMA kemungkinan untuk menggunakan metode kontrasepsi jangka panjang Intrauterine Device (IUD) sebesar 66,666 kali dibandingkan dengan wanita usia subur yang tidak sekolah.

Model kedua perbandingan antara wanita usia subur (WUS) yang menggunakan MOW dengan WUS yang menggunakan metode implan. WUS yang bekerja memiliki kemungkinan menggunakan MKJP metode MOW sebesar 5,882 kali dibanding dengan WUS yang tidak bekerja; sedangkan WUS yang bertempat tinggal di daerah perkotaan kemungkinan menggunakan MKJP metode MOW 8,196 kali dibandingkan dengan WUS yang tinggal di daerah pedesaan.

Gambar 1. Model Regresi Logistik Multinomial Penggunaan IUD

$$
P\left(Y_{1} I U D\right)=\frac{\left[3,619-1,525 \mathrm{X}_{1}-4,214 \mathrm{X}_{2}-1,072 \mathrm{X}_{3}+18,685 \mathrm{X}_{4}+18,319 \mathrm{X}_{4}-1,052 \mathrm{X}_{5}\right]}{e^{-\left[3,619-1,525 \mathrm{X}_{1}-4,214 \mathrm{X}_{2}-1,072 \mathrm{X}_{3}+18,685 \mathrm{X}_{4}+18,319 \mathrm{X}_{4}-1,052 \mathrm{X}_{5}\right]+\left[2,707-1,769 \mathrm{X}_{3}-2,103 \mathrm{X}_{4}\right]}}
$$


Gambar 2. Model Regresi Logistik Multinomial Penggunaan MOW

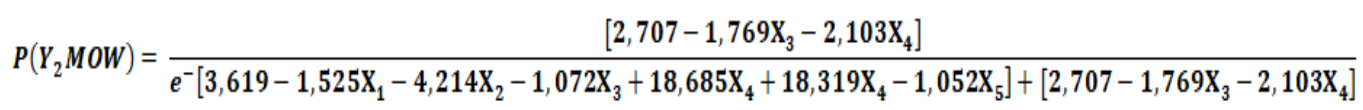

Pada gambar 1 dan 2 Model regresi logistik multinomial yang terbentuk dari nilai koefisien pada tabel 10 .

Keterangan Gambar (1 dan 2):

$\begin{array}{ll}\mathrm{P}(\mathrm{Y}) & \text { : Probabilitas penggunaan MKJP } \\ \mathrm{X} 1 & \text { : Umur } \\ \mathrm{X} 2 & \text { : Tingkat Pendidikan } \\ \mathrm{X} 3 & \text { : Jenis Pekerjaan } \\ \mathrm{X} 4 & \text { : Sumber Pelayanan } \\ \mathrm{X} 5 & \text { : Tempat Tinggal }\end{array}$

\section{PEMBAHASAN}

Berdasarkan hasil penelitian, mayoritas metode kontrasepsi jangka panjang (MKJP) yang digunakan oleh WUS di Provinsi Jawa Timur tahun 2012 adalah metode IUD. Metode IUD ini adalah metode kontrasepsi yang cukup efektif, tahan lama (hingga 10 tahun proteksi), efisien, nyaman dan biaya yang dikeluarkan relatif murah. Tingkat kegagalan pada setahun pertama sangat rendah mencapai angka $0,8 \%$. Keuntungan lainnya adalah penggunaan MKJP ini tidak bergantung pada kalender haid ataupun kepatuhan dalam meminum pil atau kunjungan ke dokter (Stoddard dkk, 2011).

Penggunaan MKJP dengan metode IUD juga tidak memiliki pengaruh terhadap lingkungan seksual, tidak ada pengaruh terhadap hormon, apabila masih program menyusui juga tidak akan mengganggu produksi ASI setelah dipasang segera setelah melahirkan. Menurut Julie Strickland, Profesor Kebidanan dan Ginekologi di University of Missouri-Kansas City (Turangan, 2016), metode IUD merupakan metode kontrasepsi yang baik, karena aman, tidak mempengaruhi kesuburan bahkan setelah melepaskannya, fleksibel menyesuaikan dengan bentuk rahim dan mudah dilepas, dan sangat efektif.

\section{Pengaruh Karakteristik WUS berdasarkan Umur terhadap Penggunaan MKJP di Provinsi Jawa Timur tahun 2012}

Permintaan penggunaan alat kontrasepsi dengan umur responden menunjukkan hubungan yang sangat bermakna. Bertambahnya umur tentu peluang responden untuk menggunakan alat kontrasepsi akan semakin tinggi. Hasil penelitian berdasarkan umur pada Tabel 2, memperlihatkan bahwa responden dengan usia dibawah 30 tahun yang menggunakan alat kontrasepsi dengan metode IUD hanya 13 orang, sebaliknya pada umur lebih dari 30 tahun cenderung menggunakan MKJP dengan metode IUD sebanyak 60 orang.

Umur ibu berhubungan dengan minat menggunakan MKJP jenis IUD. Seorang perempuan dikatakan berada pada usia produktif ketika berusia dibawah 30 tahun (BKKBN, 2010). Pada usia tersebut justru berupaya untuk dapat memiliki keturunan. Terbukti pada penelitian ini, bahwa usia dibawah 30 tahun tidak banyak yang menggunakan kontrasepsi MKJP metode IUD. Hasil penelitian ini sejalan dengan penelitian yang dilakukan oleh Nasution (2011), menemukan adanya hubungan yang signifikan antara usia dengan pemilihan MKJP. Umur berperan sebagai faktor intrinsik, yang dapat mempengaruhi struktur organ, fungsi, komposisi biokimiawi dan sistem hormonal pada suatu periode umur. Umur juga mempengaruhi seseorang dalam berpikir dan berperilaku. Seseorang dengan umur yang lebih dari 30 tahun sudah memiliki 2 (dua) anak, sehingga lebih memilih kontrasepsi dengan masa yang lebih panjang, salah satunya IUD (Bernadus, 2013). Penggunaan IUD pada umur lebih dari 30 tahun dikarenakan bertambahnya umur maka peluang untuk membatasi kelahiran juga bertambah tinggi. 


\section{Pengaruh Karakteristik WUS berdasarkan Tingkat Pendidikan terhadap Penggunaan MKJP di Provinsi Jawa Timur tahun 2012}

Tingkat pendidikan seseorang sangat berpengaruh pada orang tersebut dalam bertindak dan mencari solusi dari segala permasalahan yang ada pada hidupnya. Dengan pendidikan yang tinggi, sesorang dapat bertindak sangat rasional sehingga akan lebih mudah menerima ide gagasan baru. Pendidikan dalam arti yang sesungguhnya adalah suatu proses penyampaian materi pada sasaran yang bertujuan untuk terjadinya perubahan tingkah laku dan tujuan (Notoadmodjo, 2003). Menurut Kusumaningrum (2009), tidak selalu ada hubungan yang signifikan antara tingkat pendidikan dengan penggunaan metode kontrasepsi.

Berdasarkan hasil analisis data pada Tabel 3, menunjukkan bahwa responden yang tidak sekolah lebih banyak menggunakan metode MKJP yaitu implan sebesar $66,7 \%$. Hal ini sesuai dengan penelitian yang dilakukan oleh Magadi (2003), yang menyatakan bahwa responden yang tidak sekolah akan mempunyai peluang yang sangat kecil untuk menggunakan metode IUD. Penggunaan IUD lebih dipilih oleh responden dengan tingkat pendidikan SD dan SMP masingmasing sebanyak 29 orang. Hal ini sejalan dengan penelitian yang dilakukan oleh Nurbaiti (2013), bahwa ibu yang berada pada jenjang pendidikan yang rendah tidak menggunakan IUD dan sebaliknya pada responden dengan kriteria pendidikan tinggi lebih memilih IUD sebagai alat kontrasepsi.

Penelitian yang dilakukan oleh Nurbaiti (2013), menggambarkan bahwa pemakaian metode kontrasepsi dipengaruhi oleh tingkat pendidikan sebelumnya dengan praktek pemakaian kontrasepsi. Tingkat pendidikan ini mempempengaruhi keputusan WUS dalam memilih metode kontrasepsi.
WUS yang memiliki pendidikan lebih tinggi seperti berpendidikan SMA kemungkinan menggunakan IUD dibandingkan implan sebesar 5,26 kali dibandingkan dengan WUS yang tidak sekolah dan WUS berpendidikan SMA kemungkinan sebesar 6,02 kali dibandingkan dengan WUS yang berpendidikan SD.

\section{Pengaruh Karakteristik WUS berdasarkan Daerah Tempat Tinggal terhadap Penggunaan MKJP di Provinsi Jawa Timur tahun 2012}

WUS di Jawa Timur lebih banyak tinggal di perkotaan dan lebih memilih untuk menggunakan metode kontrasepsi IUD. Kemungkinan penggunaan IUD daripada metode Implan di daerah perkotaan sebesar 2,865 kali dibandingkan dengan WUS yang tinggal di daerah pedesaan. Faktor yang mempengaruhi WUS yang tinggal di perkotaan memiliki pendidikan yang lebih tinggi, lebih mudah untuk menjangkau fasilitas pelayanan kesehatan dan akses untuk mendapatkan informasi dari berbagai media lebih mudah didapat. Hal ini sejalan dengan penelitian yang telah dilakukan oleh Magetin (2016) yang menyatakan bahwa daerah tempat tinggal memiliki pengaruh dalam penggunaan kontrasepsi. Menurut Pastuti dan Wilopo (2007), status tempat tinggal antara perkotaan dan pedesaan dengan penggunaan $\mathrm{KB}$ menunjukkan bahwa $58,5 \%$ responden yang tinggal di perkotaan ingin membatasi dan mengatur jarak kelahiran. Namun, secara statistik tidak terdapat hubungan yang siginifikan mengenai pernyataan tersebut.

Daerah tempat tinggal responden juga memiliki hubungan yang bermakna terhadap penggunaan IUD. Responden yang tinggal di daerah perkotaan memiliki peluang lebih tinggi untuk menggunakan IUD. Hal tersebut terkait dengan ketersediaannya fasilitas yang memadai dan lebih baik dibandingkan di lingkungan pedesaan. Hasil penelitian yang dilakukan 
oleh Wilopo (1995), bahwa wanita yang tinggal di lingkungan perkotaan lebih memilih IUD karena merasa cocok dan promosi mengenai jenis alat kontrasepsi tersebut.

\section{Pengaruh Karakteristik WUS berdasarkan Pekerjaan terhadap Penggunaan MKJP di Provinsi Jawa Timur tahun 2012}

WUS yang bekerja atau memiliki pekerjaan yang menetap akan lebih memilih alat kontrasepsi MKJP karena praktis, aman dan memiliki pengaruh jangka panjang. Penggunaan MKJP ini dimaksudkan agar dapat membatasi jarak kelahiran dan membatasi jumlah anak sehingga tidak mengganggu karir dan pekerjaannya. Sejalan dengan hasil penelitian, pekerjaan mempengaruhi WUS dalam penggunaan IUD. WUS yang bekerja lebih memilih menggunakan IUD dibanding dengan menggunakan metode Implan sebesar 2,924 kali dibandingkan dengan WUS yang tidak bekerja. Untuk wanita yang bekerja, pengaturan jarak kehamilan merupakan hal yang sangat penting, karena demi mempertahankan karir yang dimiliki dan untuk mendukung perekonomian keluarga.

WUS yang memilih menggunakan

IUD lebih nyaman karena penggunaan IUD ini tidak memberikan pengaruh terhadap hormonal yang dapat mengganggu aktivitas kerja. Pada Tabel 10, hubungan pekerjaan dengan penggunaan metode IUD pada responden memiliki nilai Sig. ( $p$-value) lebih dari 0,05 yang berarti tidak adanya hubungan signifikan antara pekerjaan dengan penggunaan metode kontrasepsi jangka panjang dengan metode IUD. Hal ini sejalan dengan penelitian yang dilakukan oleh Sri Panuntun (2004) yang menyatakan bahwa pekerjaan ibu tidak ada kaitannya dengan pemilihan kontrasepsi (Wulandari, 2015). Hal tersebut juga diungkapkan dalam penelitiannya di Rumah Sakit Umum Panda Arang, Boyolali yang menyatakan mengenai hubungan pekerjaan dengan pemilihan jenis kontrasepsi. Dikatakan bahwa tidak terdapat hubungan yang signifikan antara bekerja atau tidaknya seseorang dengan pemilihan kontrasepsi, karena umumnya penggunaan kontrasepsi tidak akan menganggu aktivitas sehari-hari (Bernadus, dkk, 2013).

\section{Pengaruh Karakteristik WUS berdasarkan Sumber Pelayanan KB terhadap Penggunaan MKJP di Provinsi Jawa Timur tahun 2012}

Salah satu keberhasilan pelayanan keluarga berencana ditentukan oleh kondisi tempat pelayanan seperti sarana prasarana yang memenuhi standar baku pelayanan. Sumber pelayanan keluarga berencana dapat menjadi salah satu faktor yang mempengaruhi penggunaan metode kontrasepsi (BKKBN, 2014). Berdasarkan hasil analisis data menunjukkan bahwa sumber pelayanan keluarga berencana memiliki pengaruh terhadap wanita usia subur yang menggunakan IUD. Wanita usia subur lebih memilih memanfaatkan sumber pelayanan keluarga berencana di puskesmas paling banyak diantara fasilitas lainnya. Hal ini dikarenakan puskesmas merupakan fasilitas kesehatan pertama yang akan dituju, dapat memanfaatkan fasilitas BPJS, dan terdapat jadwal khusus dalam pelayanan $\mathrm{KB}$.

Pemilihan fasilitas kesehatan dalam hal pemasangan alat kontrasepsi jangka panjang ini tidak terlepas dari kepercayaan masyarakat, apabila masyarakat memilih memasang kontrasepsi di RS yang besar, maka masyarakat beranggapan bahwa fasilitas lengkap dan terjamin, tenaga kesehatan memiliki kualifikasi yang baik, serta kelengkapan alat bantu medis yang memadai. Perbaikan dan penyampaian pelayanan serta akses yang mudah dijangkau dapat meningkatkan proporsi pemakaian kontrasepsi.

Berdasarkan hasil analisis dalam penelitian ini, wanita usia subur yang memilih fasilitas RS pemerintah memiliki 
peluang atau kemungkinan menggunakan IUD terhadap implan sebesar 1,303 kali dibandingkan dengan WUS yang memilih fasilitas lainnya. Wanita usia subur yang memilih fasilitas Rumah Sakit swasta memiliki peluang atau kemungkinan menggunakan Intrauterine Device IUD terhadap implan sebesar 9,033 kali dibandingkan dengan wanita usia subur yang memilih pasang di fasilitas lainnya.

\section{Analisis Regresi Logistik Multinomial terhadap Penggunaan MKJP}

Pada studi kasus ini, variabel dependennya adalah metode kontrasepsi jangka panjang pada wanita menikah usia subur di Jawa Timur, dibagi menjadi 3 kategori yaitu :

$\mathrm{Y}=1$ untuk IUD

$\mathrm{Y}=2$ untuk MOW

$\mathrm{Y}=0$ untuk Implan (sebagai pembanding)

$$
\begin{aligned}
& \mathrm{g}_{1}=3,619-1,528(\mathrm{X} 1)-4,214(\mathrm{X} 2)- \\
& 1,072(\mathrm{X} 3)+18,685(\mathrm{X} 4)- \\
& 1,052(\mathrm{X} 5) \\
& \mathrm{g}_{2}=2,707-1,769(\mathrm{X} 3)-2,103(\mathrm{X} 4)
\end{aligned}
$$

Fungsi logit yang diperoleh berdasarkan estimasi parameter adalah:

Hasil penelitian menunjukkan bahwa pada fungsi logit 1 (perbandingan antara IUD dan implan) terdapat lima variabel yang berpengaruh terhadap model yaitu umur, tingkat pendidikan, pekerjaan, sumber pelayanan dan daerah tempat tinggal. Kemudian pada fungsi logit 2 perbandingan antara Medis Operasi Wanita (MOW) dan implan terdapat dua variabel yaitu pekerjaan dan dareah tempat tinggal yang berpengaruh. Sehingga diperoleh model regresi logistik multinomial seperti yang terdapat pada hasil penelitian.

Selanjutnya untuk mengetahui metode kontrasepsi jangka panjang yang memiliki probabilitas paling besar untuk dipilih oleh kelompok umur, tingkat pendidikan, pekerjaan, sumber pelayanan, dan daerah tempat tinggal tertentu maka digunakan estimasi probabilitas respon. Sebagai contoh untuk kelompok umur wus (kurang dari sama dengan 30 tahun) dikodekan dengan 0 , pendidikan (tidak sekolah) dikodekan dengan 0 , sumber pelayanan lainnya dikodekan dengan 0 , tidak bekerja dikodekan dengan 0 dan pedesaan dikodekan dengan 0 .

Berdasarkan hasil estimasi probabilitas dibawah ini, dapat dikatakan bahwa probabilitas responden umur kurang dari sama dengan 30 tahun, tidak sekolah, tidak bekerja, memasang alat kontrasepsi di sumber pelayanan lain dan bertempat tinggal di desa memilih Intrauterine Device (IUD) sebagai alat kontrasepsi sebesar 70\%, memilih Medis Operasi Wanita (MOW) 28,12\%, dan memilih implan $1,88 \%$.

Estimasi probabilitas WUS memilih IUD sebagai alat kontrasepsi:

$$
\pi_{1}=\frac{e^{3,619-1,528(0)-4,214(0)-1,072(0)+18,685(0)-1,052(0)}}{1+e^{3,619-1,528(0)-4,214(0)-1,072(0)+18,685(0)-1,052(0)}+e^{2,707-1,769(0)-2,103(0)}}=0,70002252
$$

Gambar 3. Probabilitas WUS dalam memilih IUD

Estimasi probabilitas WUS memilih MOW sebagai alat kontrasepsi:

$$
\pi_{2}=\frac{e^{2,707-1,769(0)-2,103(0)}}{1+e^{3,619-1,528(0)-4,214(0)-1,072(0)+18,685(0)-1,052(0)}+e^{2,707-1,769(0)-2,103(0)}}=0,28121011
$$

Gambar 4. Probabilitas WUS dalam memilih MOW 
Estimasi probabilitas wanita usia subur memilih Implan sebagai alat kontrasepsi:

$$
\pi_{0}=\frac{1}{1+e^{3,619-1,528(0)-4,214(0)-1,072(0)+18,685(0)-1,052(0)}+e^{2,707-1,769(0)-2,103(0)}}=0,01876735
$$

Gambar 5. Probabilitas WUS dalam memilih Implan

\section{SIMPULAN}

Berdasarkan analisis yang telah dilakukan terhadap variabel independen dengan variabel dependen, diperoleh kesimpulan antara lain: metode kontrasepsi yang paling banyak digunakan oleh WUS di Provinsi Jawa Timur tahun 2012 yaitu IUD sebanyak 43,7\%. Rata-rata pengguna metode kontrasepsi jangka panjang jenis IUD pada wanita usia subur di Provinsi Jawa Timur berumur 30 tahun ke atas dengan latar belakang pendidikan SD. Faktor yang mempengaruhi penggunaan MKJP di Provinsi Jawa Timur tahun 2012 antara lain WUS yang berumur lebih dari 30 tahun, WUS yang memiliki tingkat pendidikan yang lebih tinggi, mayoritas bertempat tinggal di daerah perkotaan dan memiliki pekerjaan.

Mayoritas wanita usia subur menggunakan metode IUD dalam menerapkan metode kontrasepsi jangka panjang, tetapi banyak metode lain yang cukup efektif, sehingga penting bagi BKKBN untuk dapat mempromosikan hal tersebut kepada wanita usia subur. Kegiatan promosi pada wanita usia subur mengenai beberapa metode kontrasepsi selain IUD dapat dilakukan pada usia dibawah 30 tahun, pada berbagai tingkat pendidikan, yang tidak memiliki pekerjaan, dan bertempat tinggal di pedesaan. Selain kegiatan mengenai promosi, dapat dilakukan dengan cara konseling, informasi, dan edukasi (KIE) melalui penyuluhan kesehatan.

Upaya penyampaian informasi yang dibutuhkan bagi bidan atau tenaga kesehatan di daerah pedesaan adanya pelatihan terhadap cara pemasangan IUD. Adanya hasil dan simpulan dari penelitian ini, dilakukan penelitian lebih lanjut untuk mengetahui faktor lain memiliki pengaruh..

\section{DAFTAR PUSTAKA}

BAPPENAS, 2012. Arah Pembangunan Kependudukan dan Keluarga Berencana dalam RKP 2012 dan Rancangan RKP 2013. Jakarta: BAPPENAS.

Bernadus. J. D., Agnes M., Gresty M. 2013. Faktor-Faktor yang berhubungan dengan Pemilihan Alat Kontrasepsi Dalam Rahim Bagi Akseptor KB di Puskesmas Jailolo. Jurnal e-NERS (eNS) Volume 1 Nomor 1. Hal.1-10.

BKKBN. 2010. Demografi dan Kependudukan Nasional. Jakarta.

BKKBN. 2014. Peranan Rumah sakit Swasta dalam mendukung pelayanan KB. Subid Bina Kesertaan $\mathrm{Kb}$ jalur Pemerintah dan Swasta.

BKKBN. 2015. Policy Brief 5: Jangan Terlena dengan Pencapaian Angka Fertilitas Total (TFR) Hasil Supas 2015 dan PMA 2015. Jakarta: Puslitbang KB dan KS.

BPS. 2013. Proyeksi Penduduk Menurut Provinsi, 2010-2035 (ribuan) BPS.

BPS. 2017. Jumlah Penduduk Provinsi Jawa Timur tahun 2016. BPS.

Hosmer, David W. Dan Lemeshow, S.Jr., 2000. Applied Logistic Regression, 2nd ed. New York. John Willey \& Sons.inc.

Kuntoro, 2007. Metode Statistik. Surabaya: Pustaka Melati.

Kusumaningrum, R., 2009. Faktor-faktor yang mempengaruhi Pemilihan jenis kontrasepsi yang digunakan pada pasangan usia subur. Karya Tulis Ilmiah. Semarang: Fakultas Kedokteran Universitas Diponegoro. 
Magadi, M.A., and Curtis. L. S. 2003.

Trends and Determinants of Contraceptive Method Choice in Kenya. Studies in Familly Planning 34 (3): 149-59.

Magetin, D. M. C., 2016. Analisis Penggunaan Metode Kontrasepsi Oleh Pasangan Usia Subur di Provinsi Jawa Timur dengan Pemodelan Regresi Logistik Multinomial. Skripsi. Universitas Airlangga.

Nasution, S. L., 2011. Faktor-Faktor Yang Berhubungan Dengan Pemakaian Kontraseps Implan Pada Akseptor KB Di Puskesmas Ciomas Kecamatan Ciomas Kabupaten Bogor Tahun 2012. Depok: UI.

Nasution, S. L. 2011. Faktor yang Mempengaruhi Pemakaian Kontrasepsi Jangka Panjang (MKJP) di Enam Wilayah Indonesia. Jakarta: Pusat Penelitian Pembangunan KB dan BKKBN.

Notoadmodjo, S. 2003. Ilmu Kesehatan Masyarakat. Jakarta: Bina Pustaka Sarwono Prawihardjo.

Nurbaiti. 2013. Faktor yang Mempengaruhi Penggunaan Alat Kontrasepsi Intra Uterine Device (IUD) di Wilayah Kerja Puskesmas Simpang Tiga Kabupaten Pidie tahun 2003. Jurnal Kebidanan. Diakses pada simtakp.stmikubudiyah.ac.id.

Pastuti, R. dan Siswanto Agus Wilopo. 2007. Determinan Penggunaan Metode Kontrasepsi IUD di Indonesia Analisis Data SDKI
2002-2003. Berita Kedokteran Masyarakat vol. 23, no. 2, Juni 2007.

Saifuddin, A., 2006. Buku Panduan Praktis Pelayanan Kontrasepsi. Jakarta: Yayasan Bina Pustaka Sarwono Prawiroharjo.

SDKI. 2013. The 2012 Indonesia Demographic and Health Survey. Jakarta. BPS, BKKBN, Kemenkes, ICF International.

Stephenson, R., Beke, dan Tshibangu, D., 2008. Community and Health Facility Influence On Contraceptive Method Choice in the Eastern Cape, South Africa. International Family Planning Perspectives, 34 (2):pp.62-70.

Stoddard, A., McNicholas, C., Peipert, J.F. 2011. Efficacy and Safety of Long Acting Reversible Contraception. Drugs 71 (8): 969-980.

Turangan, L. 2016. 7 Alasan Memilih Kontrasepsi IUD. Jakarta.

Wilopo, S. A. 1995. Dari Konsep ke Persepsi Wanita terhadap Kualitas Pelayanan Kontrasepsi, Studi Kasus di Yogyakarta. Pusat Penelitian Pranata Pembangunan, Universitas Indonesia.

Wulandari, S. 2015. Hubungan Faktor Sosial Budaya dengan Keikutsertaan KB IUD di Puskesmas Mergangsan Kota Yogyakarta tahun 2013. Jurnal Medika Respati vol. 10 nomor 1 Januari 2015 ISSN: 1907-3887. 